Мельничук В. В., асистент

Полтавська державна аграрна академія

Назаренко О. С., завідувач

Тарасівська дільнична лікарня ветеринарної медицини

Назаренко С. І., інспектор ветеринарної медицини

Гребінківський район

\title{
БІОХІМІЧНІ ЗМІНИ В СИРОВАТЦІ КРОВІ СВИНЕЙ ХВОРИХ НА ТРИХУРОЗ
}

\section{Рецензент - кандидат ветеринарних наук О. С. Клименко}

Наведені результати гематологічних досліджень щзодо визначення впливу збудника трихурозу свиней на біохімічні показники сироватки крові інвазованих тварин. Встановлено, щзо паразитування трихурисів в організмі поросят призводить до достовірного зниження вмісту загального білка, альбумінів $i$ зростання вмісту загального білірубіну, непрямого білірубіну й активності ферментів у сироватці крові. Отримані дані свідчать про залучення у патологічний процес паренхіми печінки, серчевого м'яза $i$ гладенької мускулатури кишечника.

Ключові слова: свині, трихуроз, біохімічні показники, сироватка крові

Постановка проблеми. Свинарство - одна 3 найважливіших і прибуткових галузей тваринництва - займає перше місце за скоростиглістю, плодючістю та виходом м'яса й сала. Свинина $€$ джерелом біологічно повноцінних і висококалорійних поживних речовин, вона багата повноцінним білком, екстрактивними і мінеральними речовинами, вітамінами (групи В, вітамін Е) та іншими біологічно активними сполуками. Свиняче сало - важливе джерело ненасичених жирних кислот. На якість свинини впливає вік, вгодованість, породні особливості, методи розведення тварин, годування та умови утримання, а також їх стан здоров'я $[1,4,8]$.

Серед сільськогосподарських тварин свині найчастіше піддаються різного роду захворюванням, у тому числі й інвазійним. 3-поміж числа паразитарних захворювань найбільшу шкоду завдають гельмінтози, до яких відноситься й трихуроз $[3,9]$.

Аналіз основних досліджень і публікацій, у яких започатковано розв'язання проблеми. Взаємини між паразитом і хазяїном побудовані на тонкій молекулярно-біологічній основі. У зв'язку з цим патогенна роль гельмінтів не обмежується виключно механічною, токсичною та інокуляторною дією на організм хазяїна. Не останнє місце має й стан реактивності організму хазяїна, його імунологічна та алергічна перебудова [2]. Критерієм патогенної дії паразитів на організм $\epsilon$ не лише зміна маси тіла тварини, але й суттєві зміни в крові, що живить уражені паразитами органи і тканини [5]. Більшість дослідників вважає, що за виникнення гельмінтозів змінюються передусім фракції білків. Зокрема встановлено, що зараження свиней трихурисами не викликає істотних змін у рівні загального білка і його фракцій. Інші дослідники вказують на те, що трихуриси призводять до зниження рівня загального білка, альбумінів і достовірного підвищення вмісту альфа-глобулінів у сироватці крові хворих поросят $[6,7]$. Таким чином, вивчення взаємин між паразитом і хазяїном за трихурозу свиней має як теоретичне, так і практичне значення, оскільки дасть змогу зрозуміти патогенез даної інвазії.

Метою досліджень було вивчення біохімічних змін у сироватці крові свиней, хворих на трихуроз. У завдання досліджень входило: визначити вміст білка та білкових фракцій, а також активність ферментів у інвазованих трихурисами свиней і порівняти отримані показники 3 аналогічними у клінічно здорових тварин.

Матеріал і методи досліджень. Дослідження проводилися впродовж осінньо-зимового періоду 2014 року на базі племінного свиногосподарства «Надія» Полтавського району. Біохімічні дослідження сироватки крові хворих тварин проводили в централізованій сертифікованій біохімічній лабораторії м. Полтава. Для дослідів використовували поросят великої білої породи віком 2-4 місяці, спонтанно інвазованих трихурисами з інтенсивністю інвазії 148,8 $\pm 5,12$ яєць у 1 г фекалій. Для експерименту було сформовано дві групи тварин по 5 голів у кожній (всього 10 голів). Перша група була контрольною (клінічно здорові поросята), друга - дослідною (поросята, спонтанно уражені Trichuris suis). Проби крові у свиней відбирали зранку перед годівлею з очного венозного синусу. 
ВЕТЕРИНАРНА МЕДИЦИНА

Біохімічні показники сироватки крові клінічно здорових та хворих на трихуроз поросят (n=5)

\begin{tabular}{|c|c|c|}
\hline Показники & Клінічно здорові поросята & $\begin{array}{c}\text { Поросята хворі } \\
\text { на трихуроз }\end{array}$ \\
\hline Загальний білок, г/л & $57,4 \pm 0,67$ & $50,6 \pm 1,50^{* *}$ \\
\hline Альбуміни, г/л & $22,2 \pm 0,37$ & $18,6 \pm 0,4^{* * *}$ \\
\hline Глобуліни, \% & $61,32 \pm 0,31$ & $62,94 \pm 1,79$ \\
\hline Коефіціснт альб./глоб. & $0,63 \pm 0,01$ & $0,58 \pm 0,05$ \\
\hline Білірубін: загальний, мкмоль/л & $6,4 \pm 0,4$ & $8,6 \pm 0,4^{* *}$ \\
прямий, мкмоль/л & $2,2 \pm 0,2$ & $2,8 \pm 0,2$ \\
\hline непрямий, мкмоль/л & $4,2 \pm 0,37$ & $5,8 \pm 0,37^{*}$ \\
\hline АсАТ, МО/л & $40,6 \pm 1,28$ & $46 \pm 2,09$ \\
\hline АлАТ, МО/л & $53,4 \pm 2,58$ & $91,4 \pm 10,53^{* *}$ \\
\hline Коефіцієнт АсАТ/АлАТ & $0,74 \pm 0,03$ & $0,54 \pm 0,07^{*}$ \\
\hline ГГТП, МО/л & $46 \pm 2,6$ & $57,8 \pm 2,37^{*}$ \\
\hline Лужна фосфатаза, МО/л & $594,2 \pm 6,29$ & $691,2 \pm 36,36^{*}$ \\
\hline ЛДГ, МО/л & $1203 \pm 123,1$ & $1509 \pm 10,05^{*}$ \\
\hline$\alpha$-амілаза, МО/л & $3835 \pm 250,5$ & $4563 \pm 184,2^{*}$ \\
\hline
\end{tabular}

Примітка: * - $\mathrm{P}<0,05 ; * *-\mathrm{P}<0,01 ; * * *-\mathrm{P}<0,001$ відносно показників клінічно здорових поросят

Окремі біохімічні показники досліджували за допомогою автоматичного біохімічного аналізатора «SAPPHIRE-400» (виробництва Японіï). Підготовку проб і визначення конкретних показників проводили згідно з інструкцією до приладу та реактивів («HUMAN», Німеччина).

У сироватці крові визначали вміст загального білка, білкових фракцій, коефіцієнт альбумінів до глобулінів (А/Г), вміст білірубіну (загального, прямого, непрямого), активність аспартатамінотрансферази (АсАТ), аланінамінотрансферази (АлАТ), гаммаглутамілтранспептидази (ГГТП), лужної фосфатази (ЛФ), лактатдегідрогенази (ЛДГ), $\alpha$-амілази.

Статистичну обробку результатів експериментальних досліджень проводили шляхом визначення середнього арифметичного (М), його похибки (m) та рівня вірогідності (p) з використанням таблиці t-критеріїв Стьюдента.

Результати дослідження. Результати отриманих даних наведені у таблиці. Встановлено, що в інвазованих трихурисами поросят достовірно знижувався вміст загального білка $(50,6 \pm 1,50$ г/л, $\mathrm{P}<0,01)$ на $11,8 \%$, порівняно 3 показниками клінічно здорових тварин $(57,4 \pm 0,67$ г/л), що відбувалося за рахунок зниження вмісту альбумінів на $16,2 \%(18,6 \pm 0,4$ г/л, $\mathrm{P}<0,001$, порівняно 3 клінічно здоровими поросятами - 22,2 $\pm 0,37$ г/л).

Одночасно достовірно зростав у сироватці крові поросят, хворих на трихуроз, вміст загального білірубіну на $25,6 \% \quad(8,6 \pm 0,4$ мкмоль/л, $\mathrm{P}<0,01)$ за рахунок зростання на $27,6 \%$ вмісту непрямого білірубіну $(5,8 \pm 0,37$ мкмоль/л, $\mathrm{P}<0,05)$, порівняно до показників у клінічно здорових тварин $(6,4 \pm 0,4$ та 4,2 $\pm 0,37$ мкмоль/л відповідно).

Характерним за трихурозу свиней було помітне збільшення активності ферментів у сироватці їх крові: АлАТ у 1,7 рази $(\mathrm{P}<0,01)$, ГГТП - у 1,3 рази $(\mathrm{P}<0,05)$, ЛФ - у 1,2 рази $(\mathrm{P}<0,05)$, ЛДГ - у 1,3 рази $(\mathrm{P}<0,05), \alpha$-амілаза - у 1,2 рази $(\mathrm{P}<0,05)$.

На підставі отриманих даних можна зробити висновок, що в результаті дії токсинів й алергенів личинок і дорослих трихурисів в організмі свиней відбуваються глибокі порушення обмінних процесів, функцій травної та кровотворної систем.

Зростання активності ферментів у сироватці крові свідчить про ураження паренхіми печінки, мускулатури кишечника, а також про глибокі порушення білкового обміну.

\section{Висновки:}

1. Трихуроз свиней супроводжується значними змінами біохімічних показників у сироватці крові інвазованих тварин.

2. Трихурозна інвазія характеризувалася гіпопротеінемією, гіпоальбунемією та збільшенням вмісту непрямого білірубіну в сироватці крові хворих поросят.

3. Зростання активності ферментів (АлАТ, ГГТП, ЛФ, ЛДГ, $\alpha$-амілази) у сироватці крові уражених трихурисами поросят вказує на ураження клітин печінки, міокарда й мускулатури кишок. 


\section{БІБЛІОГРАФІЯ}

1. Баньковский Б. Первоочередные задачи по разведению и рациональному использованию новых мясных пород свиней / Б. Баньковский // Свиноводство. - 1996. - №6. - С. 14.

2. Брезгинова Т. И. Динамика гематологических и некоторых биохимических показателей у свиней при аскариозе / Т. И. Брезгинова : [сб. науч. трудов ЛВИ и ИСХИ «Инвазионные болезни сельскохозяйственных животных»]. - Иваново, 1991. - С. 11-13.

3. Василинин М. П. Трихоцефалез свиней и меры борьбы с ним на промышленных комплексах в специализированных фермах Дальнего Востока / М. П. Василинин. - Благовещенск, 1993. C. 129.

4. Войтенко C. Миргородская порода и ее возможности / С. Войтенко, Е. Цыбенко, Е. Тур // Свиноводство. - 1996. - №4. - С. 14.

5. Даугалиева Э. Х. Особенности реактивности при гельминтозах и ее роль в системе паразит - хозяин / Э. Х. Даугалиева // Вестник сельскохозяйственных наук. - 1984. - №1. - С. 125-126.

6. Красников Ю. В. Динамика белковой картины сыворотки крови поросят в норме и при трихоцефалезе / Ю. В. Красников // Тр. Саратовской научно-исследовательской ветстанции. - 1970. T. 8. - C. 138-143.

7. Медзявичюс А. Иммунологические и биохимические изменения при трихоцефалезе поросят / А. Медзявичюс, В. Кучюкас // Acta parasitological Lituanica. - 1973. - T. 11. - C. 121-124.

8. Шуст О. А. Економічні засади виробництва та реалізації продукції свинарства в сільськогосподарських підприємствах / О. А. Шуст // Сталий розвиток економіки. - 2011. - №1 (4). C. 276-280.

9. Kirkprick C. H. Immunr responses to helminth infection / C. H. Kirkprick // J. Immunol. - 1993. Vol. 150. - P. 1873. 